\title{
Synthesis, Characterization, and Solid-State Structural Chemistry of An(IV) Aliphatic Dicarboxylates
}

Aphra V. Murray, Jennifer N. Wacker, Jefferey A. Bertke and Karah E. Knope*

Department of Chemistry, Georgetown University, $37^{\text {th }}$ and O Streets NW, Washington, D.C, 20057, United States

\section{ELECTRONIC SUPPLEMENTAL INFORMATION}

\section{TABLE OF CONTENTS}

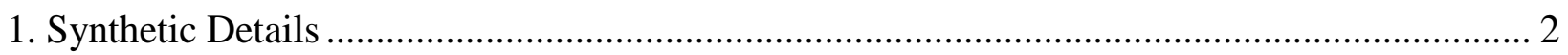

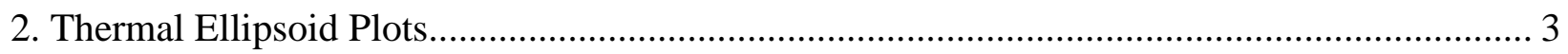

3. Crystallographic Refinement Details ........................................................................... 7

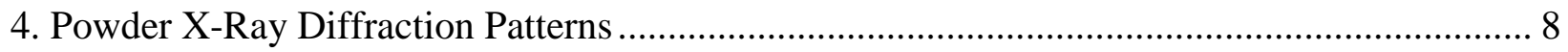

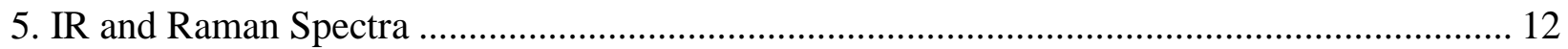

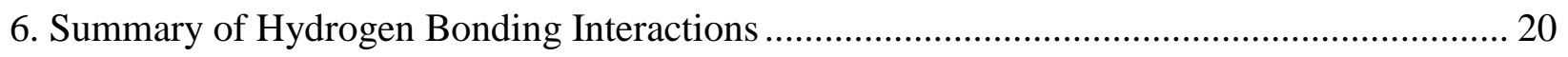

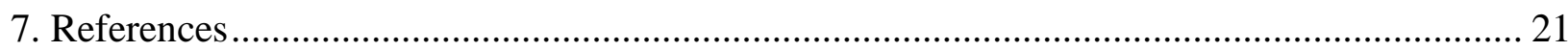




\section{Synthetic Details}

Th-1a/b

$\left[\mathrm{Th}(\mathrm{MA})_{2}\left(\mathrm{H}_{2} \mathrm{O}\right)_{3}\right]_{n}$

Malonic acid $(0.0218 \mathrm{~g}, 0.2 \mathrm{mmol})$ was dissolved in ethanol $(500 \mu \mathrm{L}, 8.5 \mathrm{mmol})$ and layered onto a solution of $\mathrm{ThCl}_{4}(0.048 \mathrm{~g}, 0.13 \mathrm{mmol})$ in water $(600 \mu \mathrm{L}, 33.3 \mathrm{mmol})$. Two distinct layers were observed. A grey precipitate was observed at the solvent interface that dissolved after about 48 hours. After a few days, colorless rectangular blocks (Th-1a) and colorless prisms (Th-1b) were observed on the walls of the vial. Approximately two weeks later, the crystals were washed with water and ethanol and left to dry under $\mathrm{N}_{2}$. For both Raman and IR vibrational spectroscopy, crystals were manually separated from the bulk product using a microscope.

\section{U-1a}

$\left[\mathrm{U}(\mathrm{MA})_{2}\left(\mathrm{H}_{2} \mathrm{O}\right)_{3}\right]_{n}$

Malonic acid $(0.0218 \mathrm{~g}, 0.2 \mathrm{mmol})$ was dissolved in ethanol $(500 \mu \mathrm{L}, 8.5 \mathrm{mmol})$ and layered onto a solution of $\mathrm{UCl}_{4}(0.049 \mathrm{~g}, 0.13 \mathrm{mmol})$ in water $(600 \mu \mathrm{L}, 33.3 \mathrm{mmol})$. Two distinct layers were observed. A grey precipitate was observed at the solvent interface that dissolved after about 48 hours. After a few days, green blocks were observed on the walls of the vial. Approximately two weeks later, the crystals were washed with water and ethanol and left to dry under $\mathrm{N}_{2}$.

U-1a: $\left[\mathrm{U}(\mathrm{MA})_{2}\left(\mathrm{H}_{2} \mathrm{O}\right)_{3}\right]_{n}$; yield based on $\mathrm{U}$ : $74 \%$; elemental analysis for $\mathrm{UC}_{6} \mathrm{O}_{11} \mathrm{H}_{10}$ : calc(obs) $\mathrm{C}$ : $14.52 \%$ (14.61\%); N: $0.0 \%$ (0.0\%); H: $2.03 \%$ (2.02\%)

\section{$\mathrm{U}-5$}

$\left[\mathrm{U}_{2} \mathrm{Cl}_{6}(\mathrm{HGA})_{2}\left(\mathrm{H}_{2} \mathrm{O}\right)_{2}\right]_{n}$

Glutaric acid $(0.303 \mathrm{~g}, 0.23 \mathrm{mmol})$ was dissolved in ethanol $(500 \mu \mathrm{L}, 8.5 \mathrm{mmol})$ and layered onto a solution of $\mathrm{UCl}_{4}(0.05 \mathrm{~g}, 0.13 \mathrm{mmol})$ in water $(600 \mu \mathrm{L}, 33.3 \mathrm{mmol})$. Two distinct layers were observed. A grey/green precipitate was observed at the solvent interface that dissolved after about 48 hours. After a few days, green blocks were observed on the walls of the vial. Approximately two weeks later, the crystals were washed with water and ethanol and left to dry under $\mathrm{N}_{2}$. Yield based on $\mathrm{U}$ : $62 \%$; elemental analysis for $\mathrm{U}_{2} \mathrm{Cl}_{6} \mathrm{C}_{10} \mathrm{O}_{10} \mathrm{H}_{22}$; calc (obs) C: $12.12 \%$ (12.36\%); $\mathrm{N}$ $0.0 \%(0.03 \%)$; H: $2.24 \%(2.19 \%)$.

\section{U-6}

$\left[\mathrm{U}_{6} \mathrm{O}_{4}(\mathrm{OH})_{4}(\mathrm{AA})_{4}\left(\mathrm{H}_{2} \mathrm{O}\right)_{8}\right] \cdot 4 \mathrm{Cl} \cdot 7\left(\mathrm{H}_{2} \mathrm{O}\right)$

Adipic acid (0.0293 g, $0.21 \mathrm{mmol})$ was dissolved in ethanol $(500 \mu \mathrm{L}, 8.5 \mathrm{mmol})$ and layered onto a solution of $\mathrm{UCl}_{4}(0.05 \mathrm{~g}, 0.13 \mathrm{mmol})$ in water $(600 \mu \mathrm{L}, 33.3 \mathrm{mmol})$. Two distinct layers were observed. A grey/green precipitate was observed at the solvent interface. After a few days, green blocks were observed on the walls of the via. Approximately two weeks later, the crystals were washed with water and ethanol and left to dry under $\mathrm{N}_{2}$. Yield based on $\mathrm{U}$ : $41 \%$; elemental analysis for $\mathrm{U}_{6} \mathrm{Cl}_{4} \mathrm{O}_{39} \mathrm{C}_{24} \mathrm{H}_{64}$; calc (obs) $\mathrm{C} 11.31 \%(11.33 \%)$; $0.0 \%(0.20 \%)$; $\mathrm{H} 2.24 \%$ (2.14\%). 


\section{Thermal Ellipsoid Plots}

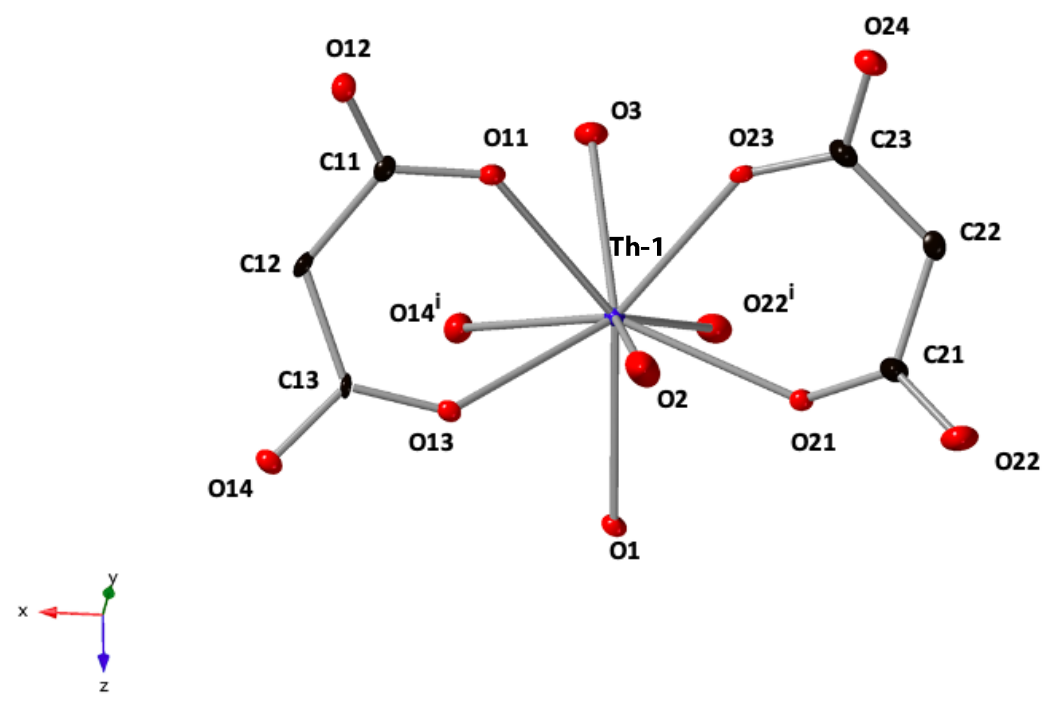

Figure S1. Thermal ellipsoid plot for Th-1a. Thermal ellipsoids are shown at 50\% probability level. Hydrogen atoms have been omitted for clarity. Blue, red and black spheres represent thorium, oxygen and carbon respectively. Superscript denotes symmetry operator: (i) $1 / 2-x, 1 / 2+y$, $1 / 2-\mathrm{Z}$.

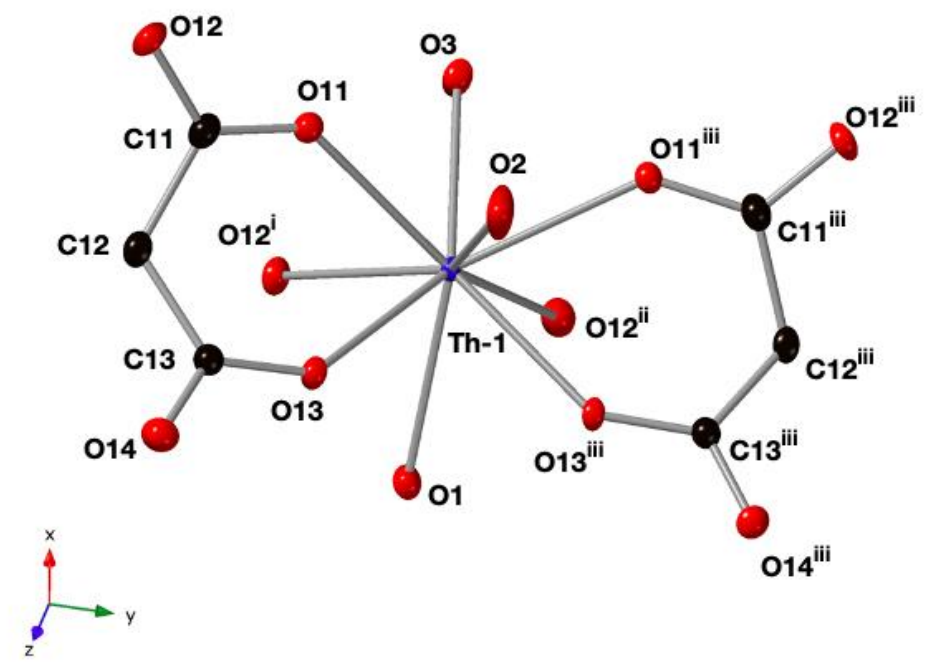

Figure S2. Thermal ellipsoid plot for Th-1b. Thermal ellipsoids are shown at 50\% probability level. Hydrogen atoms have been omitted for clarity. Blue, red and black spheres represent thorium, oxygen and carbon respectively. Superscript denotes symmetry operator: (i) $1 / 2-x, 1 / 2+y$, $1 / 2+z$, (ii) $x, 1 / 2-y, z$. 

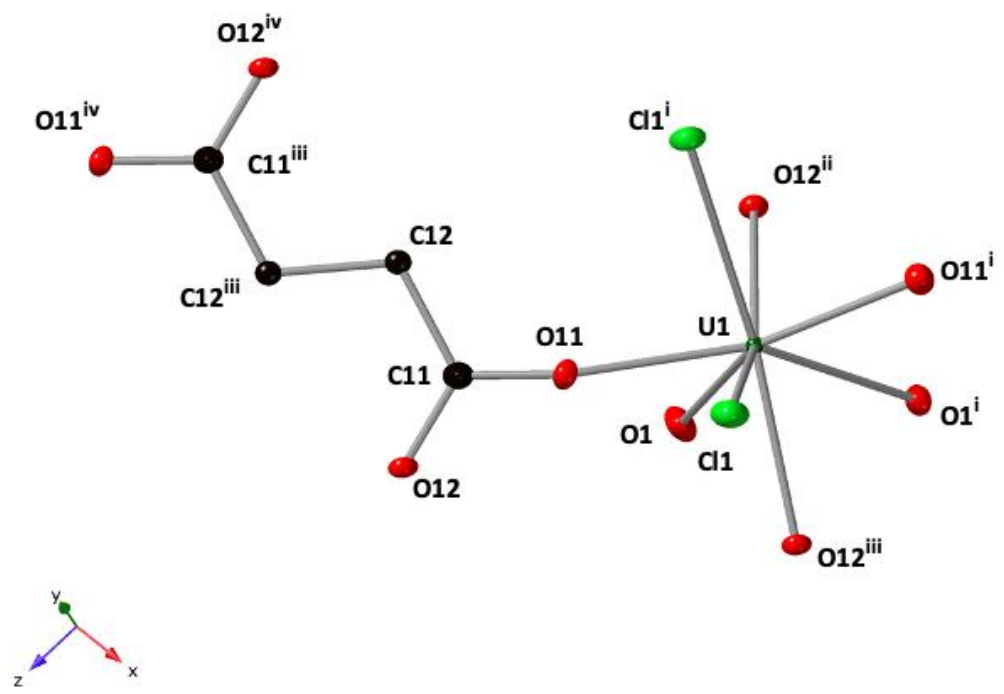

Figure S3. Thermal ellipsoid plot for U-2. Thermal ellipsoids are shown at 50\% probability level. Hydrogen atoms have been omitted for clarity. Green, red and black spheres represent uranium, oxygen and carbon respectively. Superscript denotes symmetry operator: (i) -x, y, 1/2 - z, (ii) -x, $\mathrm{y},-\mathrm{z}$, (iii) $1 / 2-\mathrm{x}, 1 / 2-\mathrm{y},-\mathrm{z}$ (iv) $\mathrm{x},-\mathrm{y}, 1 / 2+\mathrm{z}$.
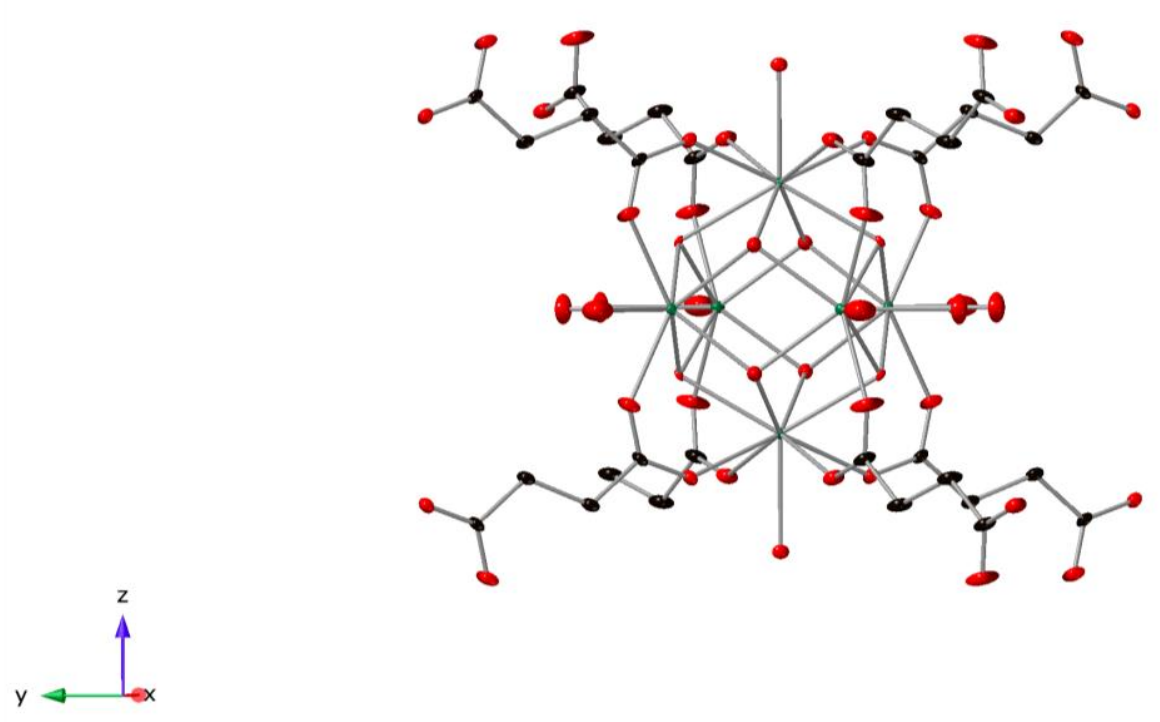

Figure S4. Thermal ellipsoid plot for U-3. Thermal ellipsoids are shown at 50\% probability level. Hydrogen atoms have been omitted for clarity. Green, red and black spheres represent uranium, oxygen and carbon respectively. 


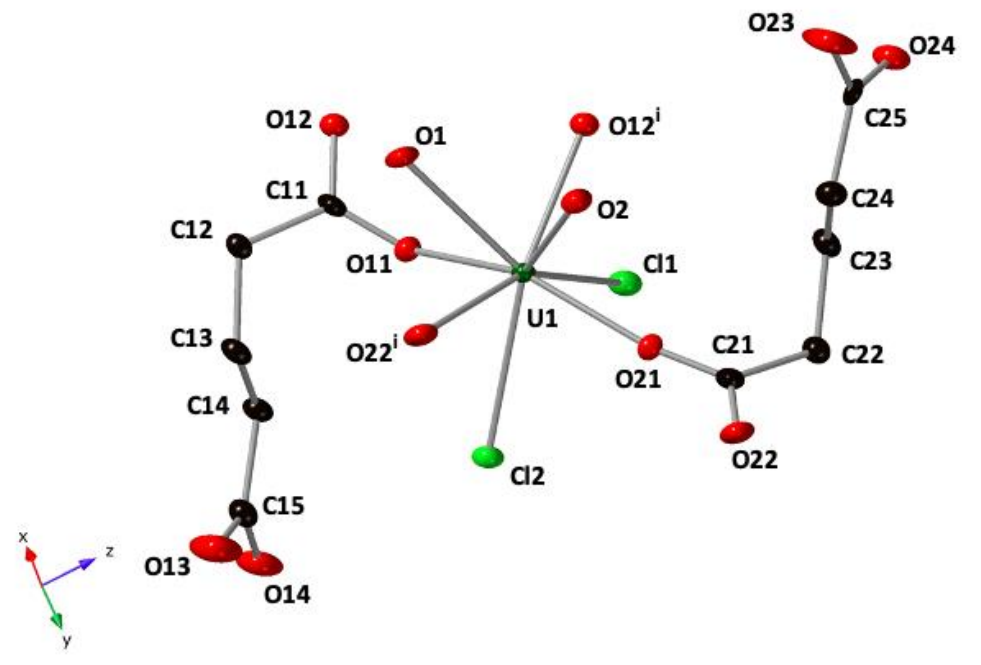

Figure S5. Thermal ellipsoid plot for U-4. Thermal ellipsoids are shown at 50\% probability level. Hydrogen atoms have been omitted for clarity. Green, red and black spheres represent uranium, oxygen and carbon respectively. Superscript denotes symmetry operators: (i) -x, -y, -z.

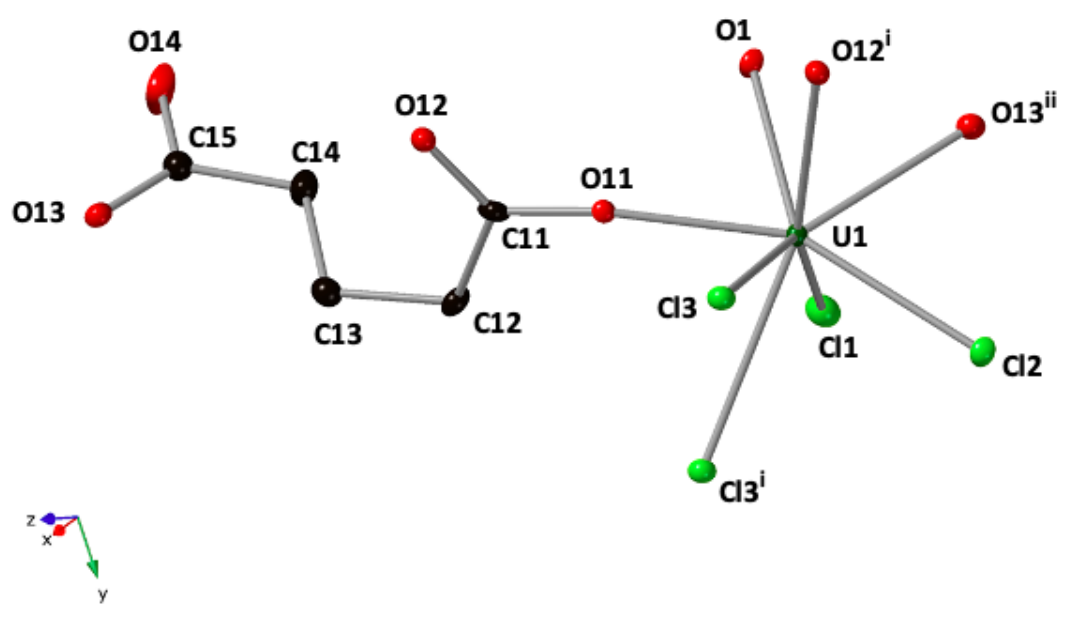

Figure S6. Thermal ellipsoid plot for U-5. Thermal ellipsoids are shown at 50\% probability level. Hydrogen atoms and disorder of the ligand have been omitted for clarity. Green, red and black spheres represent uranium, oxygen and carbon respectively. Superscript denotes symmetry operators: (i) $1 / 2-x, 1 / 2-y,-z$, (ii) $1 / 2+x, 1 / 2-y, 1 / 2+z$. 


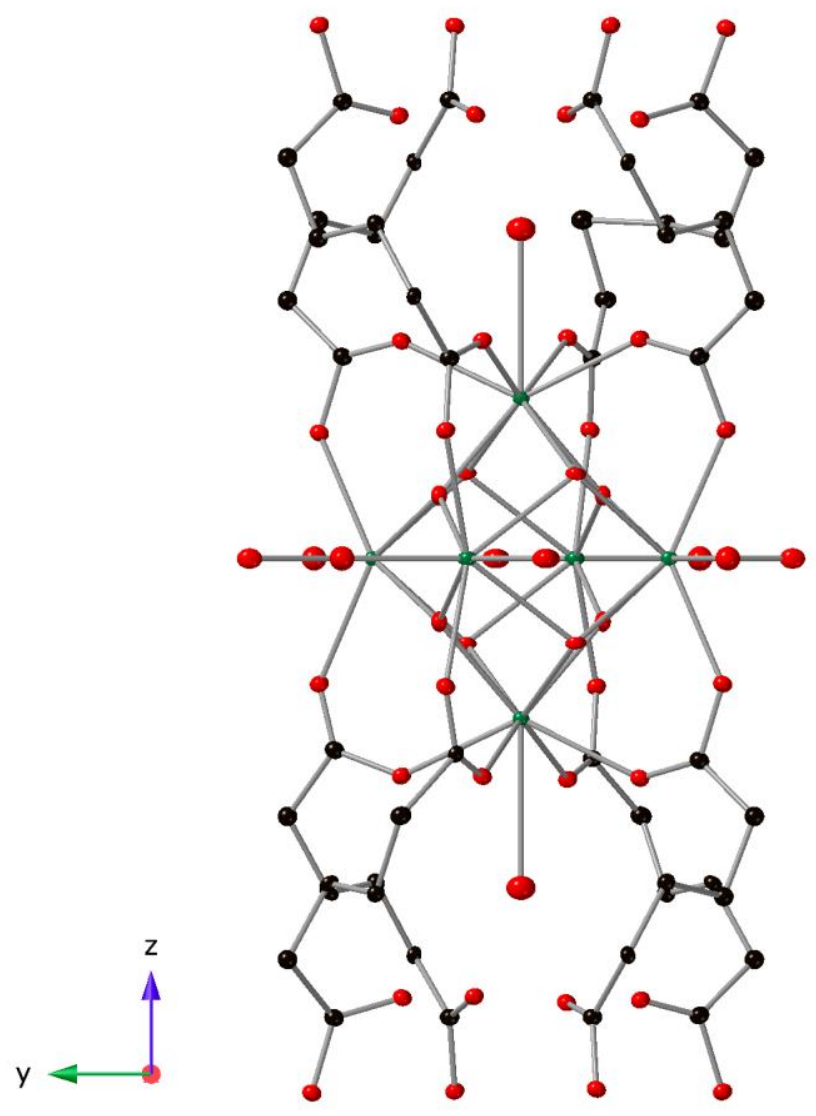

Figure S7. Thermal ellipsoid plot for U-6. Thermal ellipsoids are shown at 50\% probability level. Hydrogen atoms and disorder of the ligand have been omitted for clarity. Green, red and black spheres represent uranium, oxygen and carbon respectively. 


\section{Crystallographic Refinement Details}

All data were integrated and processed using APEX3, ${ }^{1}$ Cell Now and SAINT/TWINABS v2014/3. Twin laws were developed in PLATON. ${ }^{2}$

Th-1a: Two distinct cells were identified using APEX3 and Cell Now. Frame series were integrated and filtered for statistical outliers using SAINT then corrected for absorption by integration using SAINT/TWINABS v2014/2 to sort, merge, and scale the combined data. Combined unit cell parameters were determined from both components using SAINT. The structure was refined as a pseudo-merohedral twin. The twin law by rows was $\left(\begin{array}{llll}-1 & 0 & 0\end{array}\right)\left(\begin{array}{lll}0 & -1 & 0\end{array}\right)\left(\begin{array}{ll}0 \\ 0\end{array}\right.$ 01 ) and the ratio between the twin domains refined to 57:43. A structural model consisting of one $\mathrm{U}$ metal center, two ligands, and three coordinated water molecules per asymmetric unit was developed.

U-3: A structural model consisting of the host plus 14 disordered water solvate molecules per asymmetric unit was developed; however, positions for the idealized solvate molecules were poorly determined. This model converged with $\mathrm{wR}_{2}=0.1365$ and $\mathrm{R}_{1}=0.0374$ for 159 parameters with 24 restraints against 2338 data. Since positions for the solvate molecules were poorly determined a second structural model was refined with contributions from the solvate molecules removed from the diffraction data using the bypass procedure in PLATON. No positions for the host network differed by more than two su's between these two refined models. The electron count from the "squeeze" model converged in good agreement with the number of solvate molecules predicted by the complete refinement. The "squeezed" data are reported here.

There is substitutional disorder of the oxo/hydroxo bridging groups within the cluster. The oxo/hydroxo groups have been restrained to behave relatively isotropic. One of the coordinated water molecules is disordered over two positions. Similar displacement amplitudes (esd 0.01) were imposed on disordered sites overlapping by less than the sum of van der Waals radii.

Four reflections were omitted from the final refinement as they were obscured by the beamstop.

U-4: All crystals examined exhibited non-merohedral twinning. Two distinct cells were identified using APEX3 and Cell Now. Six frame series were integrated and filtered for statistical outliers using SAINT then corrected for absorption by integration using SAINT/TWINABS v2014/2 to sort, merge, and scale the combined data. Combined unit cell parameters were determined from both components using SAINT. The twin law by rows was $\left(\begin{array}{lll}1 & 0 & 0\end{array}\right),\left(\begin{array}{lll}-0.2 & -1 & 0\end{array}\right),\left(\begin{array}{lll}0 & 0 & -1\end{array}\right)$. Nonoverlapping reflections from the primary orientation were used for phasing and refinement. No decay correction was applied.

U-6: A structural model consisting of one half of one hexamer, one outer sphere chloride ion, and three lattice water molecules per asymmetric unit was developed. The adipate ligands are disordered over two positions across symmetry sites. The like $\mathrm{C}-\mathrm{O}$ and $\mathrm{C}-\mathrm{C}$ distances were restrained to be similar (esd $0.011 \% \mathrm{~A}$ ). All carboxylate oxygen atoms were constrained to have equal anisotropic displacement parameters. There is substitutional disorder of the oxo/hydroxo sites. Similar displacement amplitudes (esd 0.01) were imposed on disordered sites overlapping 
by less than the sum of van der Waals radii. One of the lattice water molecules is partially occupied, the site occupancy refines to $\sim 91 \%$.

\section{Powder X-Ray Diffraction Patterns}

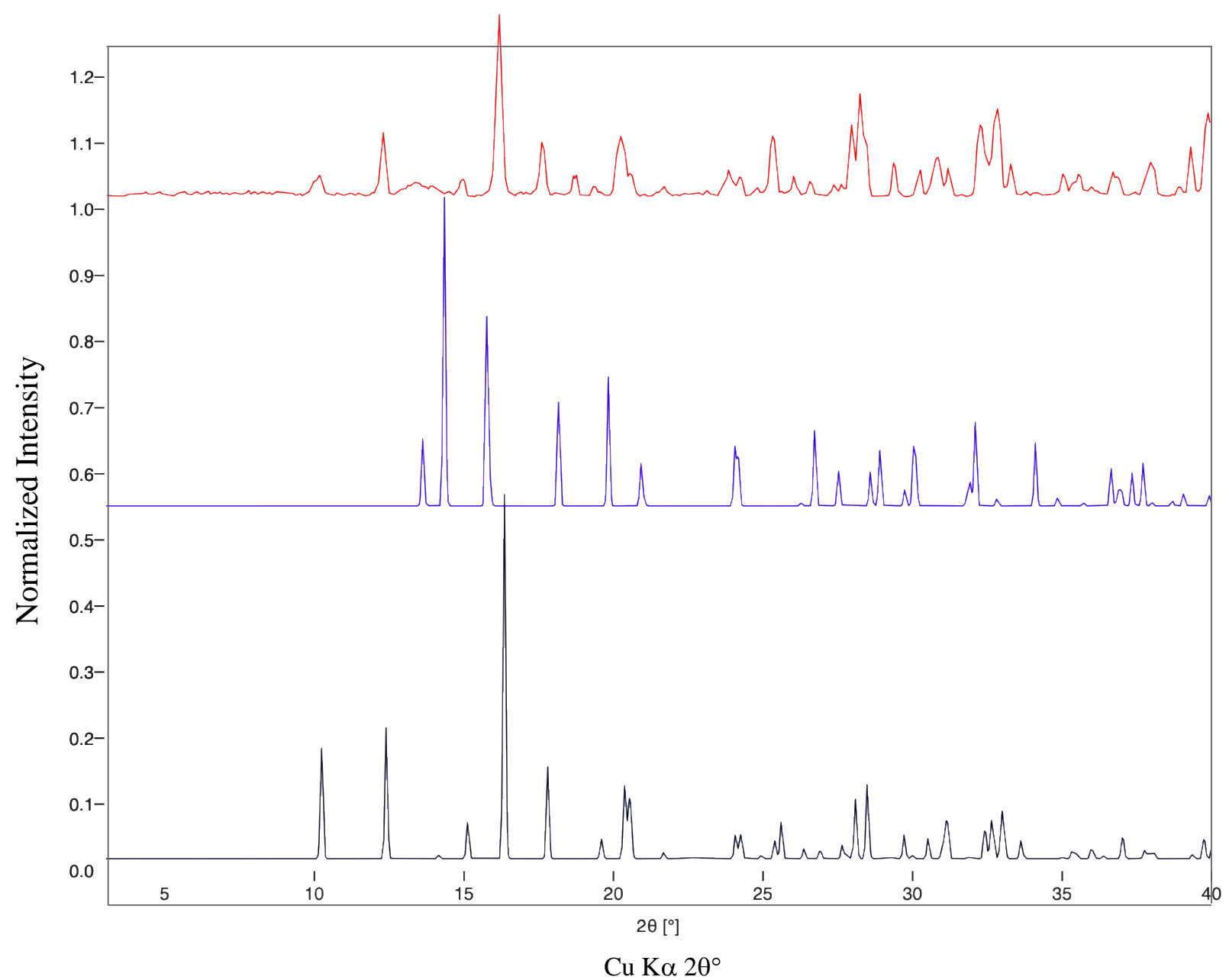

Figure S8. Powder X-ray diffraction patterns observed for the bulk reaction product from which of Th-1a/b were isolated (red) overlaid with the calculated patterns for Th-1a (black) and Th-1b (blue). 


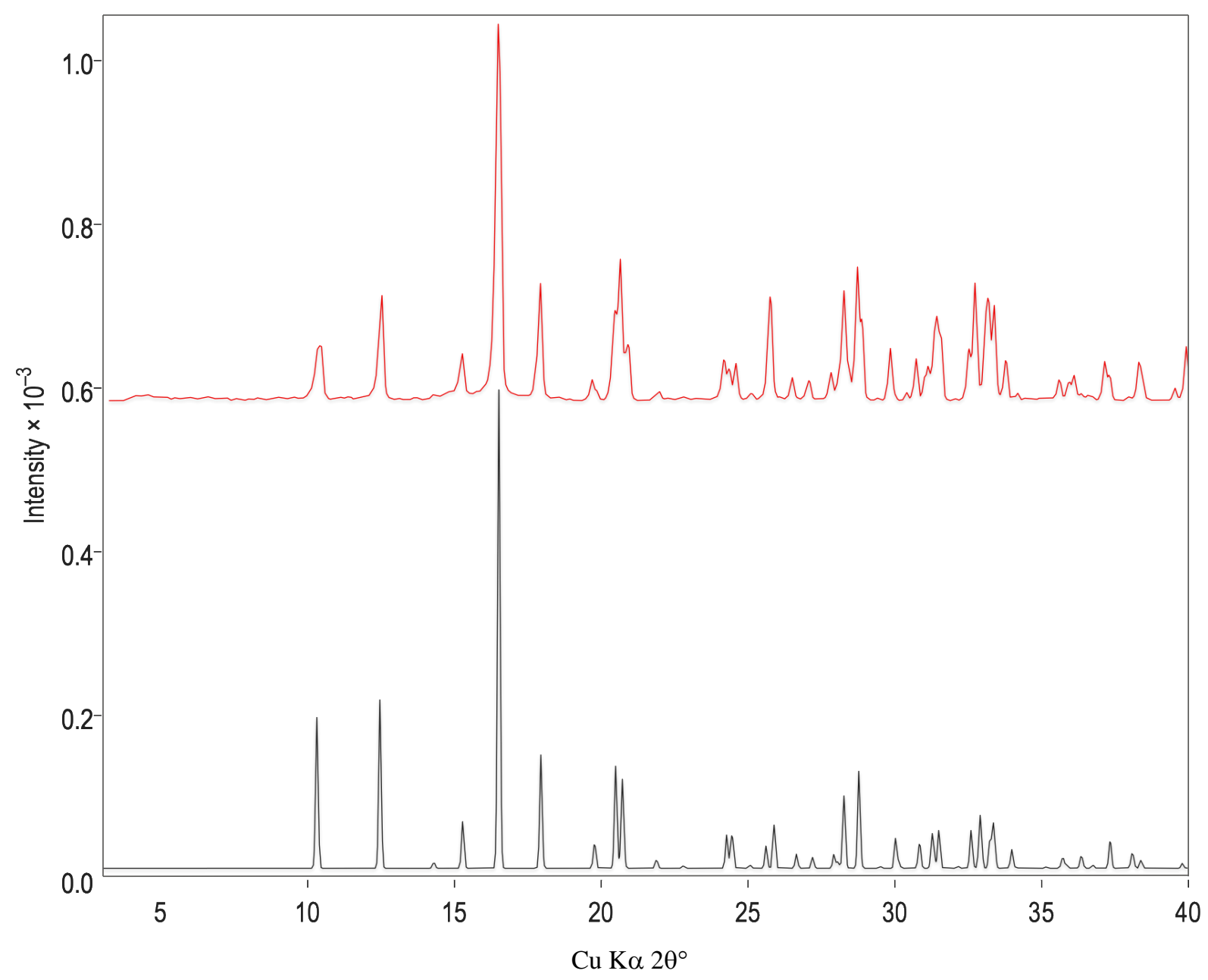

Figure S9. Powder X-ray diffraction patterns observed for the bulk reaction product that yielded U-1a (red) and the calculated pattern from the single crystal structure of Th-1a (black). Agreement between the two patterns, as well as elemental analysis and vibrational spectroscopy, confirms that the two phases are isomorphous. 


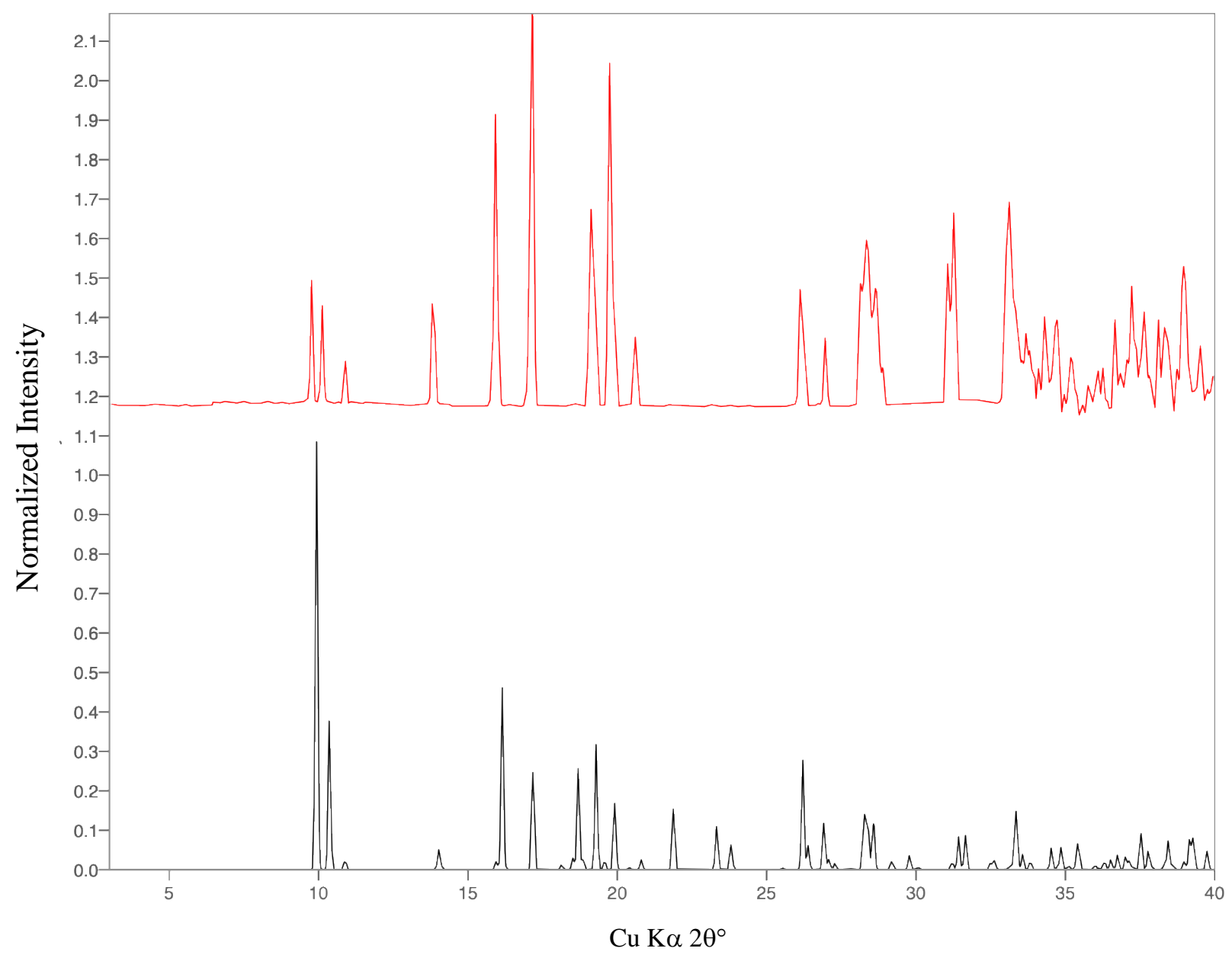

Figure S10. Powder X-ray diffraction pattern observed for the bulk sample from which $\mathbf{U}-\mathbf{5}$ was isolated (red) overlaid with the pattern calculated from the single crystal structure (black). Agreement between the calculated and experimental patterns indicate the crystals used for structure determination are representative of the bulk sample. 


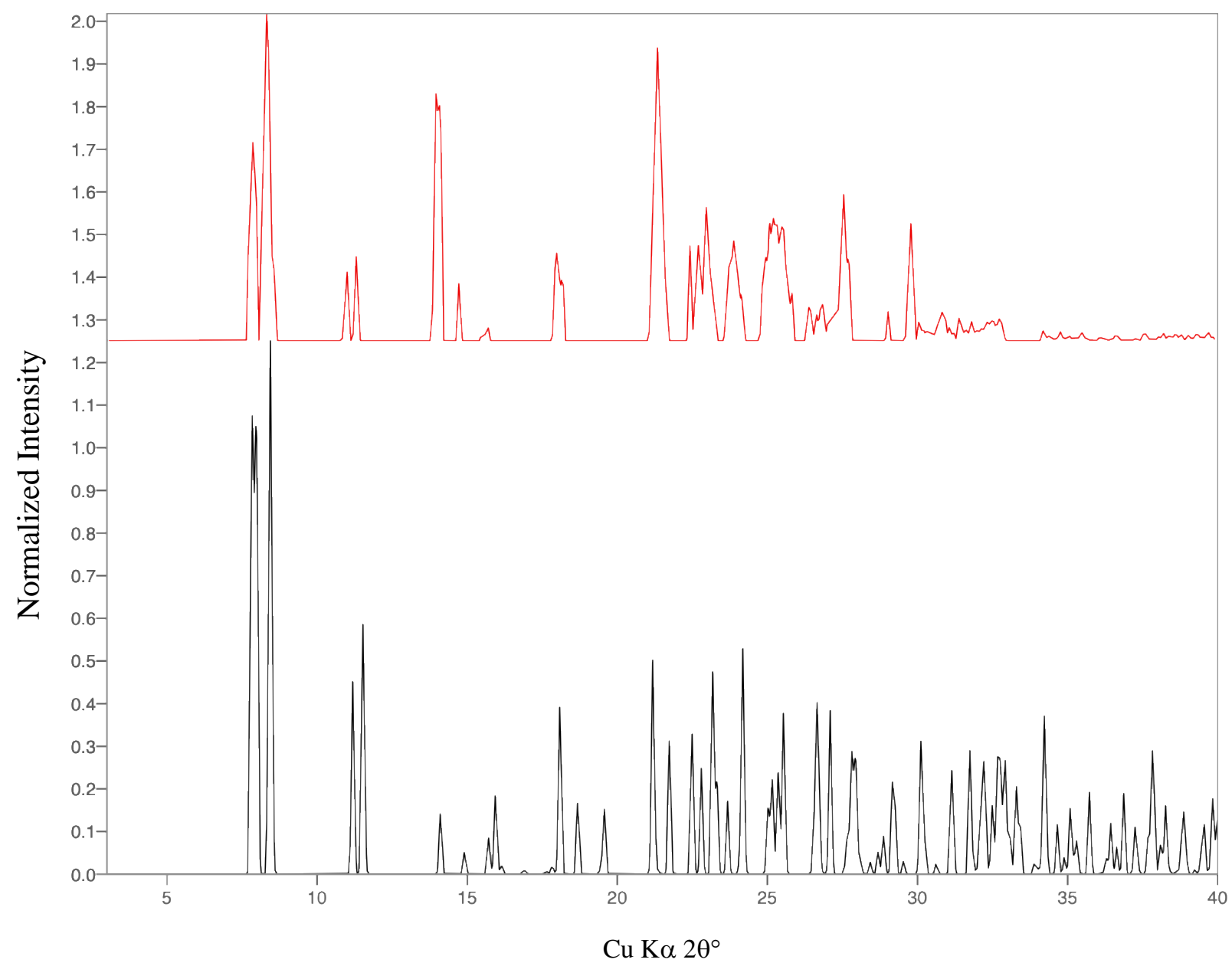

Figure S11. Powder X-ray diffraction pattern observed for bulk sample from which U-6 was isolated (red) overlaid with the pattern calculated from the single crystal structure (black). Agreement between the calculated and experimental patterns indicate the crystals used for structure determination are representative of the bulk. 


\section{IR and Raman Spectra}

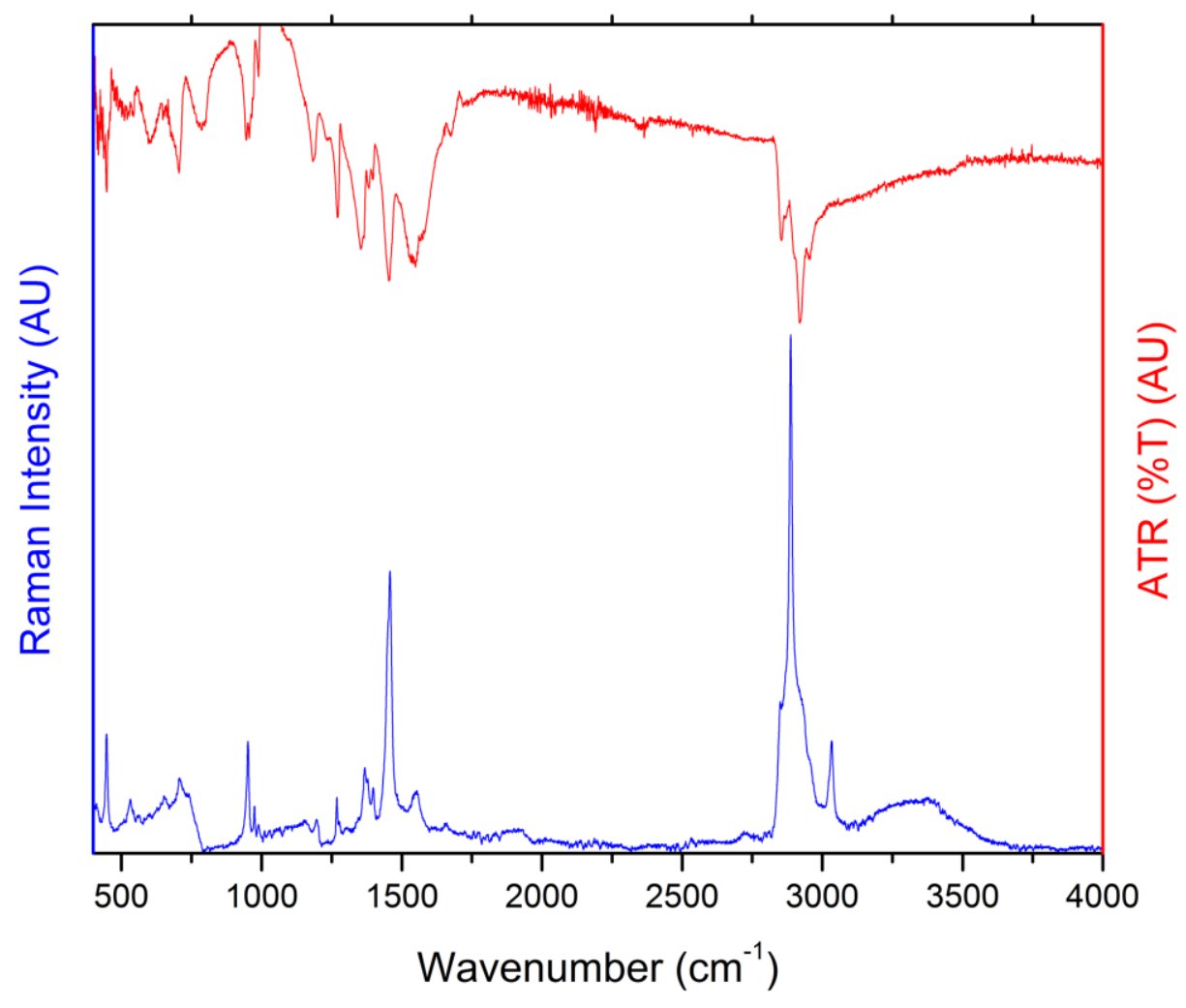

Figure S12. Infrared (red) and Raman (blue) spectra of Th-1a (red) shown over 400-4000 cm-1. IR: $\left(\mathrm{cm}^{-1}\right) 481(\mathrm{~m}), 448(\mathrm{~m}), 511(\mathrm{w}), 597(\mathrm{~m}), 705(\mathrm{~m}), 787(\mathrm{w}), 1945(\mathrm{~m}), 988(\mathrm{w}), 1183(\mathrm{w})$, 1248 (w, 1270 (m), 1350 (m), 1369 (s), 1453 (s), 1550 (s), 1568 (s), 1648 (w), 2894 (w), 2920 (s), 2956 (w), 3454 (w). Raman: $\left(\mathrm{cm}^{-1}\right) 416$ (w), 449 (m), 532 (w), 691 (w), 713 (w), 950 (m), 972 (w), $1202(\mathrm{w}), 1267(\mathrm{w}), 1316(\mathrm{w}), 1369(\mathrm{w}), 1429(\mathrm{w}), 1459$ (s), $1558(\mathrm{~m}), 2855(\mathrm{~m}), 2887(\mathrm{~s})$, 2957 (m), 3031 (m), 3368 (w, br). 


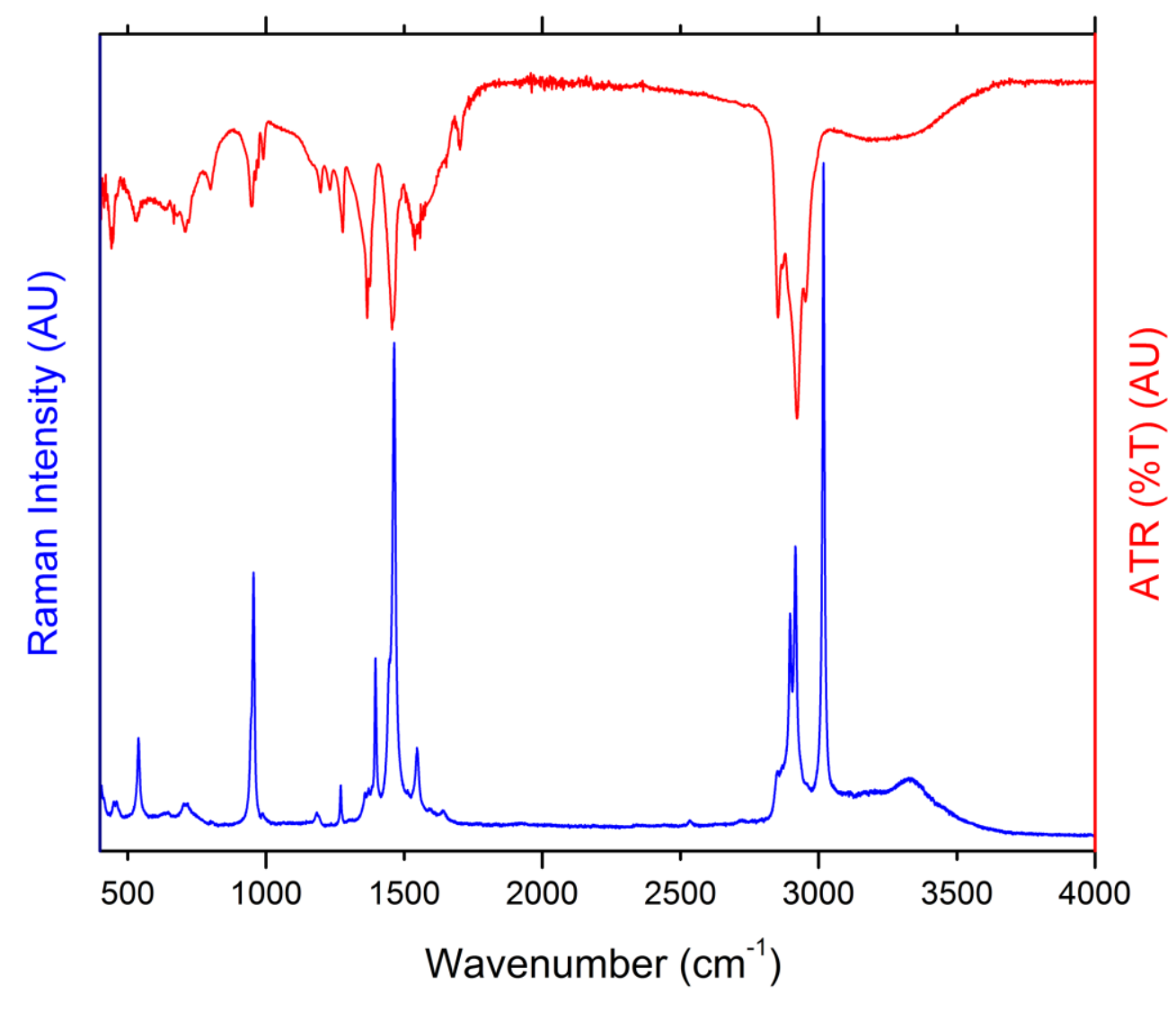

Figure S13. Infrared (red) and Raman (blue) spectra of Th-1b (red) shown over $400-4000 \mathrm{~cm}^{-1}$. IR: $\left(\mathrm{cm}^{-1}\right) 438(\mathrm{~m}), 448(\mathrm{~m}), 511(\mathrm{w}), 606(\mathrm{w}), 706(\mathrm{~m}), 787(\mathrm{~m}), 946(\mathrm{~s}), 989(\mathrm{w}), 1183(\mathrm{~m}), 1270$ (s), 1355 (s), 1454 (s), 1549 (m), 1575 (m), 1676 (w), 2855 (m), 2920 (s), 2957 (w). Raman: (cm ${ }^{-}$ 1) $448(\mathrm{w}), 485(\mathrm{w}), 541(\mathrm{~m}), 727(\mathrm{w}), 955(\mathrm{~s}), 1198(\mathrm{w}), 1271(\mathrm{w}), 1444$ (m), 1464 (vs), $1550(\mathrm{~m})$, 2858 9m), 2920 (m), 2916 (m), 3018 (vs), 3350 (w, br). 


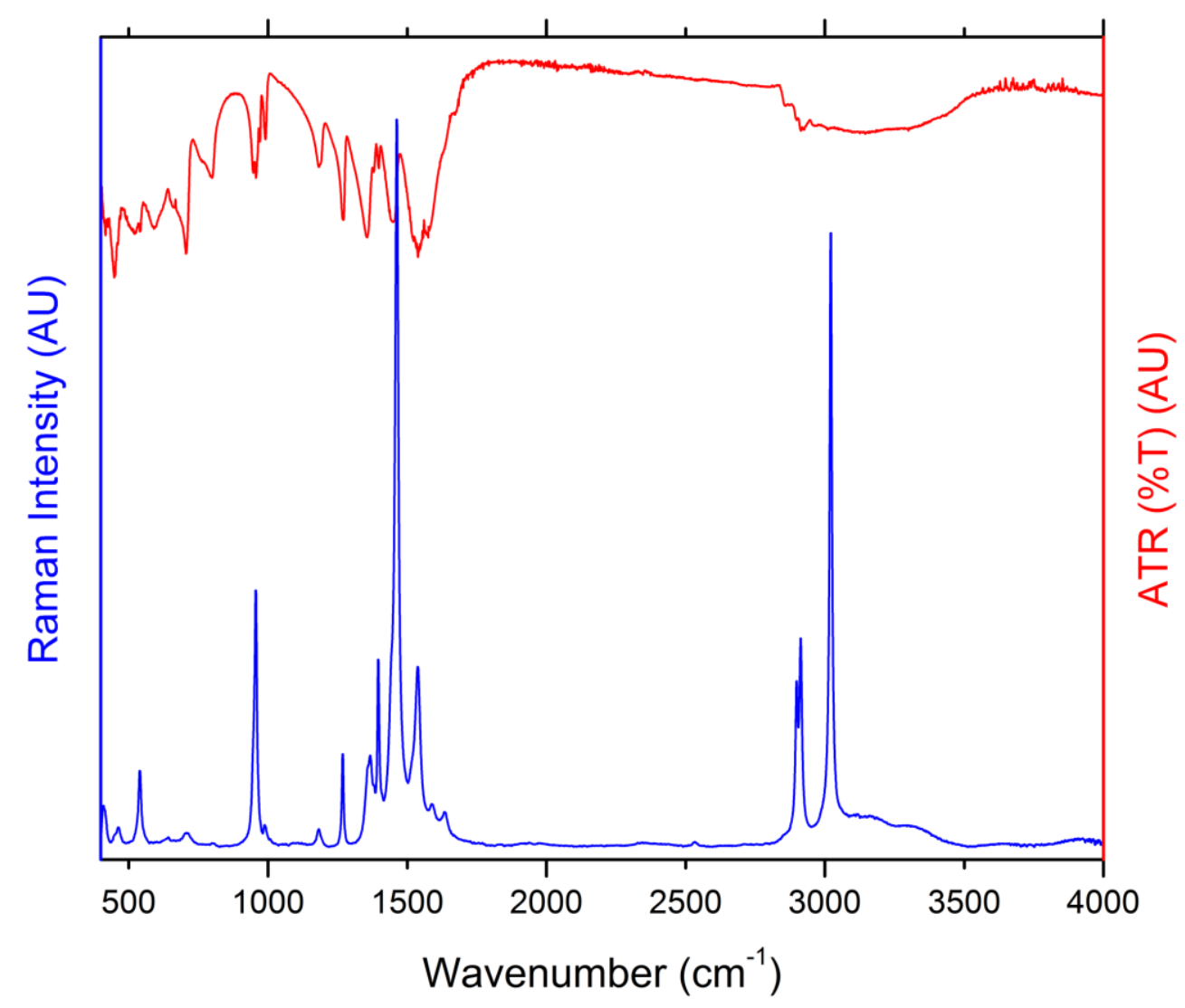

Figure S14. Infrared (red) and Raman (blue) spectra of U-1a shown over $400-4000 \mathrm{~cm}^{-1}$. IR: $\left(\mathrm{cm}^{-1}\right) 436(\mathrm{w}), 452(\mathrm{w}), 500(\mathrm{w}), 592(\mathrm{w}), 706(\mathrm{~m}), 800(\mathrm{w}), 957(\mathrm{w}), 991(\mathrm{w}), 1183(\mathrm{w}), 1272$ (m), 1357 (m), 1449 (m), 1539 (m), 1575 (m), 2893 (w), 2927 (w), 3157 (w, br). Raman: $\left(\mathrm{cm}^{-1}\right)$ 306 (w), $415(\mathrm{w}), 468(\mathrm{w}), 543(\mathrm{~m}), 718(\mathrm{w}), 955$ (s), $1189(\mathrm{w}), 1267(\mathrm{~m}), 1390(\mathrm{~m}), 1394(\mathrm{~s})$, 1463 (vs), 1540 (s), 1593 (w), 1645 (w), 2909 (m), 2912 (m), 3022 (vs), 3301 (br, w). 


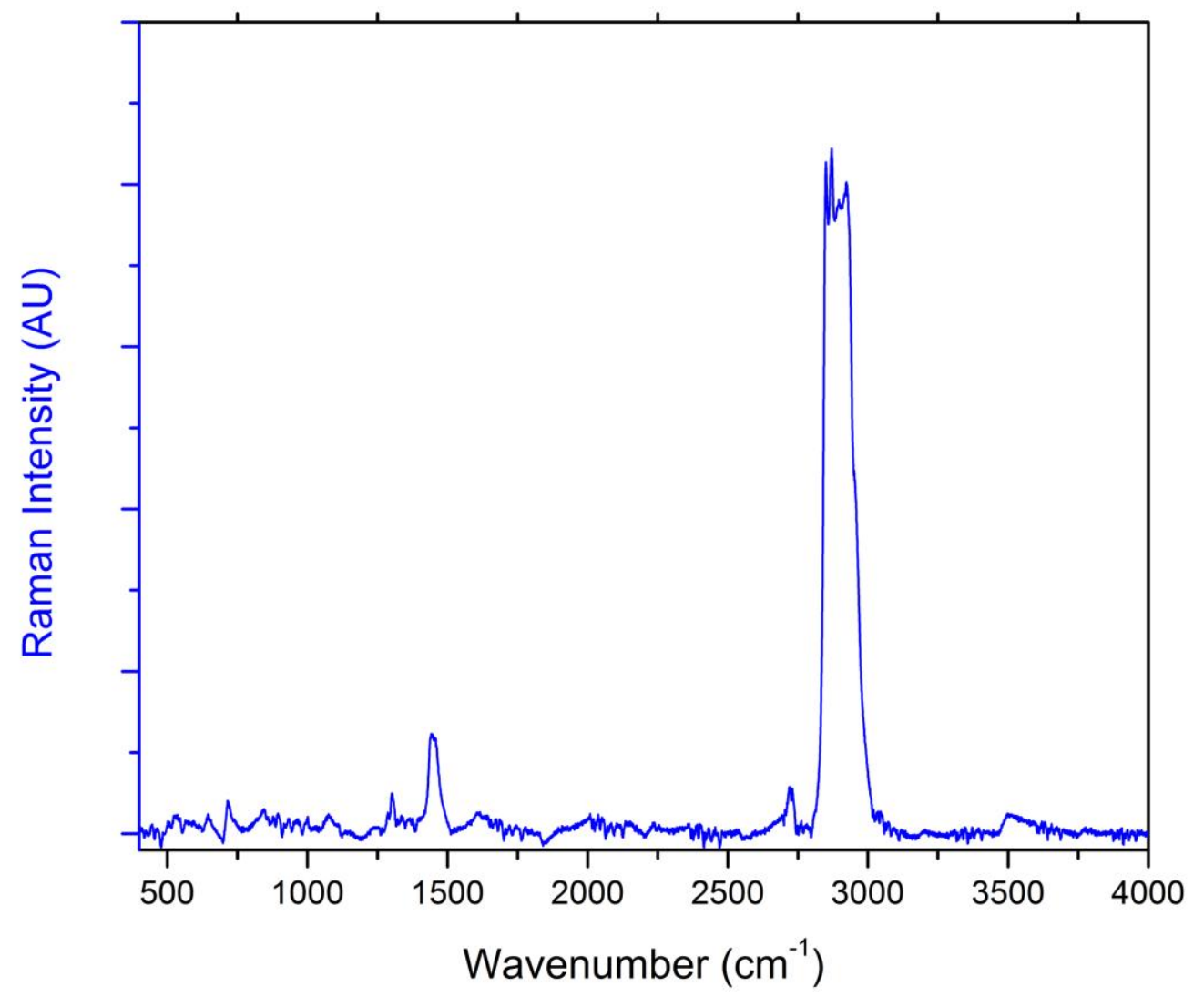

Figure S15. Raman (blue) spectrum of U-2 shown over 400-4000 $\mathrm{cm}^{-1}$. Raman: (cm $\left.{ }^{-1}\right) 543(\mathrm{w})$, 653 (w), 722 (w), 855 (w), 1003 (w), 1088 (w), 1305 (m), 1454 (m), 1617(m), 1645 (w), 2731(w), 2851 (s), 2870 (s), 2909 (s), 2926 (s), 3531 (br, w). 


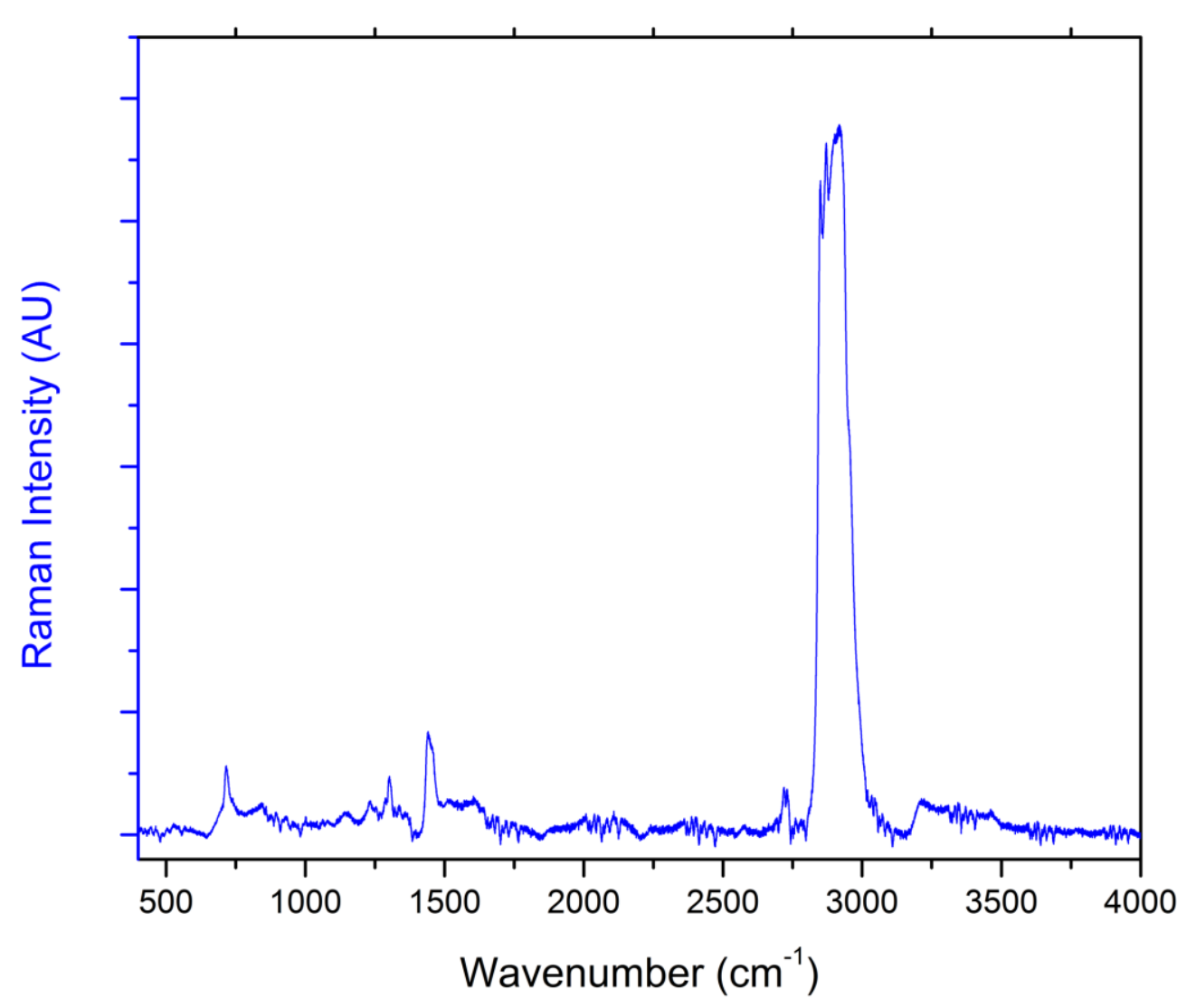

Figure S16. Raman (blue) spectrum of U-3 shown over 400-4000 $\mathrm{cm}^{-1}$. Raman: $\left(\mathrm{cm}^{-1}\right) 718(\mathrm{~m})$, $1163(\mathrm{w}), 1242(\mathrm{~m}), 1305(\mathrm{~m}), 1361(\mathrm{~m}), 1446(\mathrm{~m}), 1460(\mathrm{w}), 1524(\mathrm{w}), 1611(\mathrm{w}), 2731(\mathrm{w}), 2851$ (s), 2894 (s), 2909 (s), 2926 (s), 3226 (w), 3476 (br, w). 


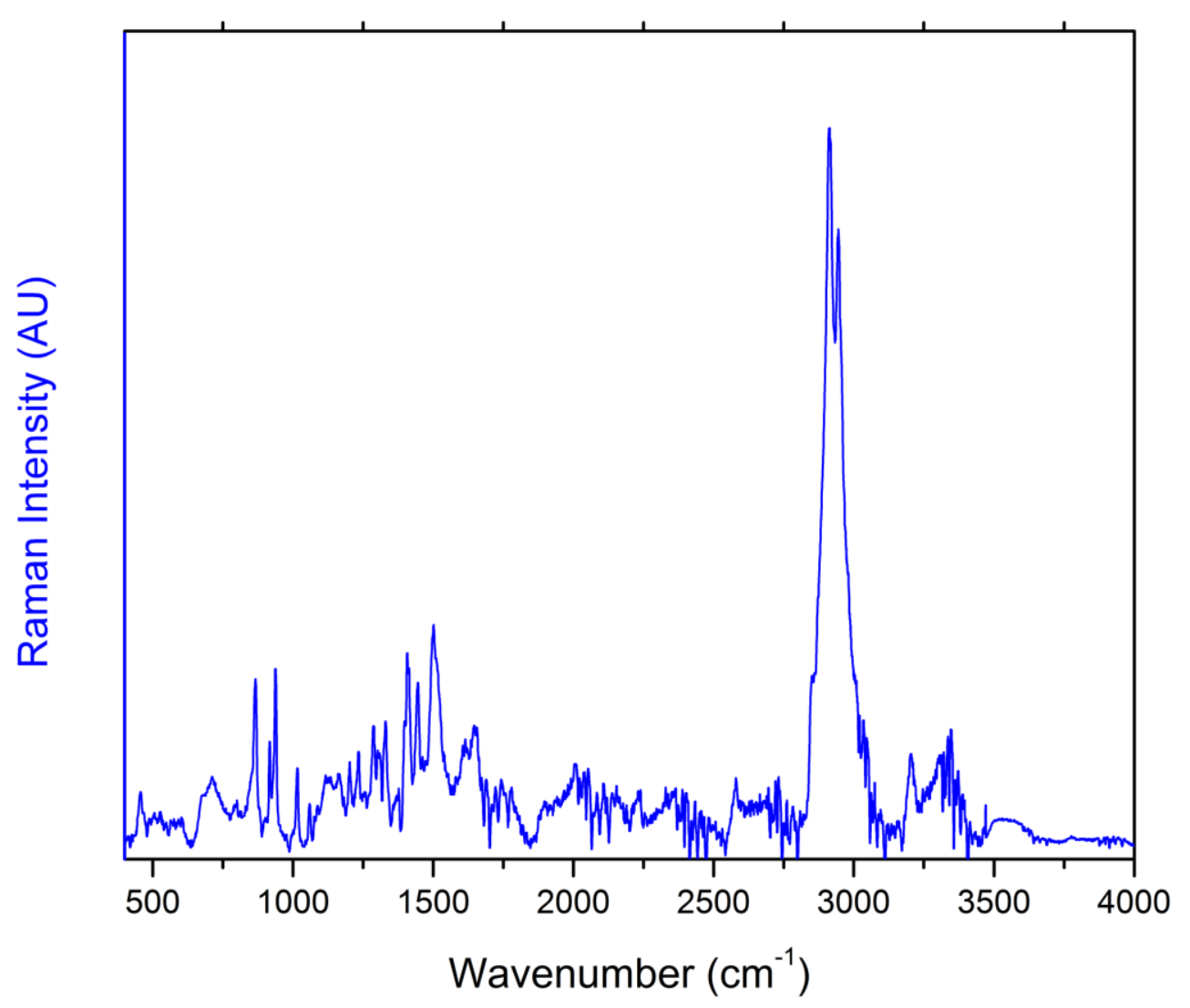

Figure S17. Raman (blue) spectrum of U-4 shown over 400-4000 cm $\mathrm{cm}^{-1}$. Raman: $\left(\mathrm{cm}^{-1}\right) 378(\mathrm{w})$, 458 (w), 723 (w), 864 (w), 939 (m), 1017 (m), 1231 (m), 1284 (m), 1332 (m), 1406 (m), 1447 (m), 1503 (m), 1658 (m), 2914 (s), 2946 (s), 3212 (w), 3557 (br, w). 


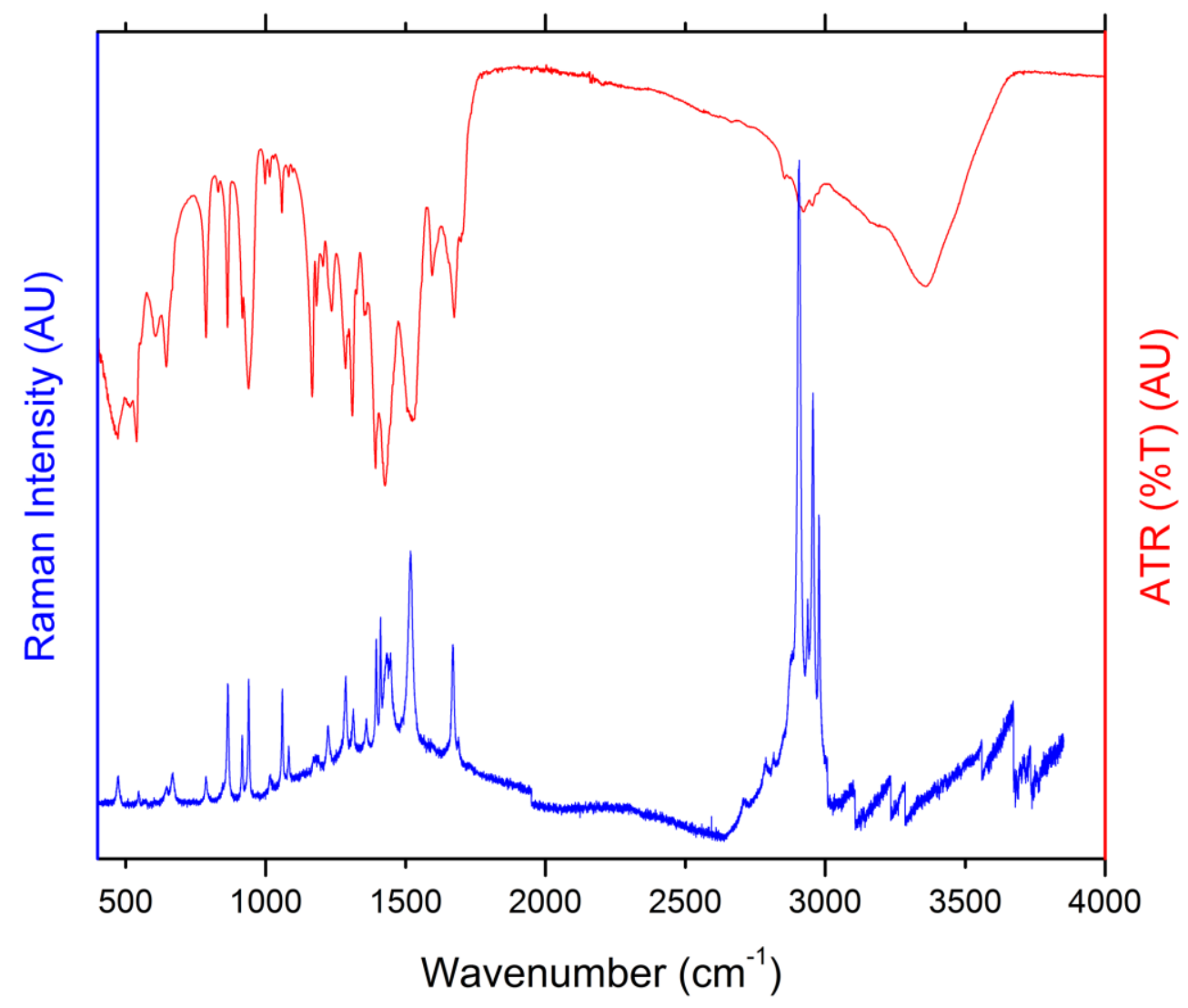

Figure S18. Infrared (red) and Raman (blue) spectra of U-5 (red) shown over $400-4000 \mathrm{~cm}^{-1}$. IR: $\left(\mathrm{cm}^{-1}\right) 473(\mathrm{~m}), 540(\mathrm{~m}), 639(\mathrm{w}), 646(\mathrm{w}), 787(\mathrm{~m}), 939(\mathrm{~s}), 1059(\mathrm{w}), 1167$ (s), $1238(\mathrm{w})$, 1305 (m), 1310 (s), 1424 (s), 1427 (s), 1533 (m), 1596 (w), 1674 (m), 1700 (w), 2858 (w), 2929 (w), 2957 (w), 3365 (w, br). Raman: (cm $\left.{ }^{-1}\right) 317$ (w), 361 (w), 472 (w), 548 (w), 651 (w), 667 (w), $787(\mathrm{w}), 865(\mathrm{w}), 916(\mathrm{~m}), 939(\mathrm{~m}), 1021(\mathrm{~m}), 1059(\mathrm{~m}), 1082(\mathrm{w}), 1223(\mathrm{~m}), 1285(\mathrm{~m}), 1312(\mathrm{~m})$, 1358 (w), 1394 (m), 1411 (m), 1445 (w), 1518 (m), 1670 (s), 2812 (vs), 2904 (vs), 2955 (vs), 2978 (vs), $3322(\mathrm{w})$. 


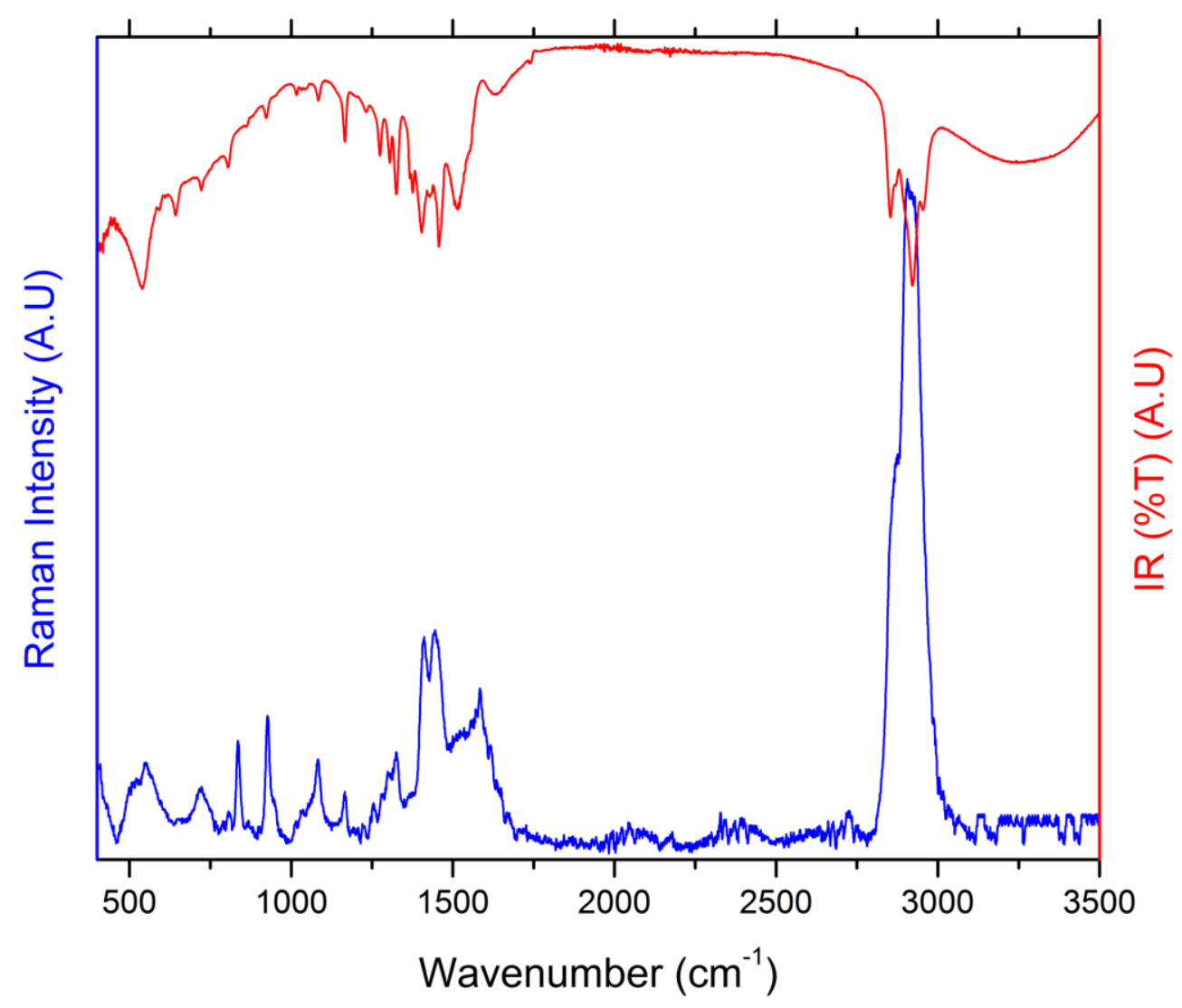

Figure S19. Infrared (red) and Raman (blue) spectra of U-6 (red) shown over $400-4000 \mathrm{~cm}^{-1}$. IR: $\left(\mathrm{cm}^{-1}\right) 541(\mathrm{w}), 643(\mathrm{w}), 722(\mathrm{w}), 806(\mathrm{w}), 924(\mathrm{w}), 1085(\mathrm{w}), 1304(\mathrm{w}), 1319(\mathrm{w}), 1325(\mathrm{~m})$, 1405 (m), 1456 (m), 1516 (w), 1640 (w, br), 2854 (m), 2924 (m), 2955 (w), 3305 (w,br). Raman: $\left(\mathrm{cm}^{-1}\right) 541(\mathrm{~m}), 725(\mathrm{~m}), 824(\mathrm{~m}), 835(\mathrm{~m}), 927(\mathrm{~m}), 1039(\mathrm{~m}), 1085(\mathrm{~m}), 1165(\mathrm{~m}), 1482(\mathrm{~s}), 1496$ (s), 1583 (m), 2727 (vs), 2749 (vs). 


\section{Summary of Hydrogen Bonding Interactions}

All hydrogen bonding interactions were calculated using PLATON. ${ }^{2}$

Table S1. Representative hydrogen bonding interactions for Th-1a.

\begin{tabular}{|l|c|c|}
\hline Interaction & Distance $(\AA)$ donor-acceptor & Angle $\left(^{\circ}\right)<\mathrm{D}-\mathrm{H}---\mathrm{A}$ \\
\hline $\mathrm{O}(1)-\mathrm{H}$--- $\mathrm{O}(12)$ & $2.854(8)$ & $161(6)$ \\
\hline $\mathrm{O}(1)-\mathrm{H}$--- $\mathrm{O}(24)$ & $2.748(8)$ & $174(7)$ \\
\hline $\mathrm{O}(2)-\mathrm{H}$--- $\mathrm{O}(3)$ & $2.769(7)$ & $149(6)$ \\
\hline $\mathrm{O}(2)-\mathrm{H}---\mathrm{O}(12)$ & $2.729(8)$ & $176(7)$ \\
\hline $\mathrm{O}(3)-\mathrm{H}$--- $\mathrm{O}(11)$ & $2.921(7)$ & $162(7)$ \\
\hline $\mathrm{O}(3)-\mathrm{H}$--- $\mathrm{O}(23)$ & $2.774(7)$ & $120(4)$ \\
\hline $\mathrm{O}(3)-\mathrm{H} \mathrm{---} \mathrm{O}(24)$ & $2.943(8)$ & $171(7)$ \\
\hline
\end{tabular}

Table S2. Representative hydrogen bonding interactions for Th-1b.

\begin{tabular}{|l|c|c|}
\hline Interaction & Distance $(\AA)$ donor-acceptor & Angle $\left(^{\circ}\right)<\mathrm{D}-\mathrm{H}---\mathrm{A}$ \\
\hline $\mathrm{O}(1)-\mathrm{H}---\mathrm{O}(14)$ & $2.840(3)$ & $170(2)$ \\
\hline $\mathrm{O}(2)-\mathrm{H}---\mathrm{O}(14)$ & $2.751(3)$ & $151(3)$ \\
\hline $\mathrm{O}(3) \mathrm{H}---\mathrm{O}(13)$ & $2.705(3)$ & $177(3)$ \\
\hline
\end{tabular}

Table S3. Representative hydrogen bonding interactions for U-2.

\begin{tabular}{|l|c|c|}
\hline Interaction & Distance $(\AA)$ donor-acceptor & Angle $\left(^{\circ}\right)<\mathrm{D}-\mathrm{H}---\mathrm{A}$ \\
\hline $\mathrm{O}(1)-\mathrm{H}---\mathrm{Cl}(1)$ & $3.118(3)$ & $161(3)$ \\
\hline
\end{tabular}

Table S4. Representative hydrogen bonding interactions for $\mathbf{U}-\mathbf{4}$.

\begin{tabular}{|l|c|c|}
\hline Interaction & Distance $(\AA)$ donor-acceptor & Angle $\left(^{\circ}\right)<\mathrm{D}-\mathrm{H}---\mathrm{A}$ \\
\hline $\mathrm{O}(1)-\mathrm{H}$--- $\mathrm{Cl}(2)$ & $3.225(5)$ & $167(5)$ \\
\hline $\mathrm{O}(2)-\mathrm{H}$--- $\mathrm{Cl}(1)$ & $3.171(5)$ & $150(6)$ \\
\hline $\mathrm{O}(13)-\mathrm{H}$--- $\mathrm{O}(24)$ & $2.628(7)$ & $173(7)$ \\
\hline $\mathrm{O}(23)-\mathrm{H}---\mathrm{O}(14)$ & $2.655(8)$ & $171(6)$ \\
\hline
\end{tabular}

Table S5. Representative hydrogen bonding interactions for U-5.

\begin{tabular}{|l|c|c|}
\hline Interaction & Distance $(\AA)$ donor-acceptor & Angle $\left(^{\circ}\right)<\mathrm{D}-\mathrm{H}---\mathrm{A}$ \\
\hline $\mathrm{O}(1)-\mathrm{H} \mathrm{---} \mathrm{Cl}(1)$ & $3.152(4)$ & $155(5)$ \\
\hline
\end{tabular}


Table S6. Representative hydrogen bonding interactions for U-6.

\begin{tabular}{|l|c|c|}
\hline Interaction & Distance $(\AA)$ donor-acceptor & Angle $\left({ }^{\circ}\right)<\mathrm{D}-\mathrm{H}---\mathrm{A}$ \\
\hline $\mathrm{O}(3)-\mathrm{H} \mathrm{---} \mathrm{Cl}(1)$ & $3.045(6)$ & $150(5)$ \\
\hline $\mathrm{O}(4)-\mathrm{H} \mathrm{---} \mathrm{Cl}(1)$ & $3.125(6)$ & $112(17)$ \\
\hline $\mathrm{O}(5)-\mathrm{H}$--- $\mathrm{O}(8)$ & $2.602(8)$ & $173(19)$ \\
\hline $\mathrm{O}(9)-\mathrm{H}$--- $\mathrm{Cl}(1)$ & $3.258(8)$ & $134(6)$ \\
\hline $\mathrm{O}(9)-\mathrm{H}---\mathrm{O}(13 \mathrm{~B})$ & $3.090(7)$ & $125(7)$ \\
\hline $\mathrm{O}(9)-\mathrm{H}---\mathrm{O}(23)$ & $3.190(3)$ & $134(7)$ \\
\hline $\mathrm{O}(9)-\mathrm{H} \mathrm{---} \mathrm{O}(11)$ & $3.200(5)$ & $165(8)$ \\
\hline $\mathrm{O}(9)-\mathrm{H} \mathrm{---} \mathrm{Cl}(1)$ & $3.289(9)$ & $165)$ \\
\hline
\end{tabular}

\section{References}

1. Bruker. APEX3, SADABS, SAINT, SHELXTL, XCIF, XPREP, Bruker AXS, Inc.: Madison, Wisconsin, USA, 2016.

2. L., S. A., Single-crystal structure validation with Platon. J. Appl. Crys. 2003, 36, 7-13. 